\title{
G. H. Mead e o valor de sua teoria para a educação
}

\author{
Artur José da Renda Vitorino' \\ Pedro Serafim Anes Pires'
}

\section{RESUMO}

Neste artigo são apresentados a teoria psicossocial e pragmatista erigida pelo filósofo americano George Herbert Mead (1863-1931) e seu valor para a educação escolar no presente. Mediante uma detalhada análise da obra, com apoio de comentadores, Mead é situado no contexto acadêmico de sua época, delineando-se os preceitos de seu pensamento e a idiossincrasia entre seus pares. Seu legado consiste num arcabouço teórico multidisciplinar - tratando-se de psicologia, sociologia e educação, interligados - em uma linguagem clara e acessível, tendo sempre como princípio norteador a mediação e a construção do self, por intermédio da interação simbólica. O presente trabalho também se baseou em comentadores brasileiros e estrangeiros que estudaram Mead, mas oferece um enfoque diferente de como as ideias do filósofo poderiam ser úteis em elucidar questões pertinentes à educação escolar, tais como inclusão, bullying e papel social da escola.

PALAVRAS-CHAVE

G. H. Mead; pragmatismo; educação; interacionismo simbólico.

'Pontifícia Universidade Católica de Campinas, Campinas, SP, Brasil. 


\section{G. H. MEAD AND THE VALUE OF HIS THEORY FOR EDUCATION}

\section{ABSTRACT}

This article addresses the psychosocial and pragmatist theory constructed by American philosopher George Herbert Mead (1863-1931) and his value for school education in the present. Throughout a detailed analysis of his works, supported by the works of commenters, Mead is situated in the scholar context of his time, and the precepts of his ideas are delineated in contrast with that of his peers. His legacy consists of a multidisciplinary framework that is intertwined - psychology, sociology, and education, presented in a clear and accessible language, always having the mediation and construction of one's self as guiding principle, through symbolic interaction. This work is also based on foreign and Brazilian authors who studied the works of Mead and saw his value for education, but offers a different perspective of how the ideas of this philosopher could help address school education issues, such as inclusion, bullying, and the social role of schools.

KEYWORDS

G. H. Mead; pragmatism; education; symbolic interactionism.

\section{G. H. MEAD Y EL VALOR DE SU TEORÍA PARA LA EDUCACIÓN}

\section{RESUMEN}

Este artículo presenta la teoría psicosocial y pragmática erigida por el filósofo estadounidense George Herbert Mead (1863-1931) y su valor para la educación escolar actual. A través de un análisis detallado de su trabajo, con el apoyo de comentaristas, Mead se sitúa en el contexto académico de su tiempo, delineando los preceptos de su pensamiento y su idiosincrasia entre sus pares. Su legado consiste en un marco teórico multidisciplinario - psicología, sociología y educación interconectadas - presentado en un lenguaje claro y accesible, siempre teniendo como principio rector la mediación y construcción del self a través de la interacción simbólica. Este documento también se basó en comentaristas brasileños y extranjeros que estudiaron a Mead, pero ofrece un enfoque diferente sobre cómo las ideas de Mead podrían ser útiles para dilucidar cuestiones relacionadas con la educación escolar, como la inclusión, el bullying y el papel social de la escuela.

\section{PALABRAS CLAVE}

G. H. Mead; pragmatismo; educación; interaccionismo simbólico. 


\section{DO ESTÍMULO AO GESTO}

\section{GEORGE HERBERT MEAD}

O mundo objetivo, num sentido muito estrito, compreende tudo aquilo que simplesmente é, de forma autônoma e anterior a quaisquer percepções ou valorações, sendo real, independentemente da avaliação subjetiva de qualquer agente e, por isso mesmo, objetivo. Infere-se daí um sentido estrito demais, equivocado, na ótica de George Herbert Mead, autor cujo pensamento jamais se entregou ao pleno relativismo, mas de igual maneira se afastou do realismo ingênuo positivista.

George Herbert Mead nasceu no estado americano de Massachusetts no ano de 1863, segundo filho de um casal de professores religiosos. Nessa segunda metade do século XIX, a filosofia americana ainda seguia próxima à europeia, de maneira especial a filosofia alemã, na qual estavam em voga - em continuidade ao pensamento de Immanuel Kant e suas definições de sintético e analítico, ideal e transcendental — o idealismo alemão, estabelecido por Georg Hegel (falecido em 1831), e o neokantismo; o marxismo na política; e a fenomenologia de Edmund Husserl, estudo filosófico da constituição e dinâmica da psicologia humana, anterior a Sigmund Freud e à sua psicanálise; enquanto Arthur Schopenhauer e Friedrich Nietzsche buscavam o sentido da existência humana. Essas foram as origens da filosofia continental, isto é, europeia, excluindo-se a Grã-Bretanha, termo que já era usado pelo utilitarista inglês J. S. Mill para contrapor a tradição filosófica britânica — empirista e utilitarista — às demais (Glock, 2008).

Por ocasião de um convite do pai para lecionar em uma universidade em New Hampshire, Mead mudou-se para esse estado com a família, no qual permaneceu por um breve período, até o pai receber uma nova proposta, para lecionar na Universidade de Oberlin, Ohio, onde Mead passou sua juventude, ingressando na mesma faculdade em que seus pais atuavam (Souza, 2011, p. 372). Mas o jovem Mead, entrando na universidade durante um período de secularização, afastou-se do dogmatismo religioso dos pais. Desde os primeiros anos de sua formação, em Oberlin (Souza, 2011, p. 372), foi conhecedor e adepto da teoria darwiniana ${ }^{1}$ da evolução das espécies e das ciências naturais como um todo; um pensador secular conhecedor da imagem do mundo natural que a ciência de sua época apresentava, dispensando quaisquer explicações místicas ou teleológicas e afastando quaisquer pressupostos dualistas. Assim sendo, sua teoria psicossocial jamais negou o papel da biologia para a psicologia e o fato de ela ser um substrato necessário para os próprios mecanismos de interação social e da construção do self, no entanto tampouco os reduziu a essa esfera.

A fim de compreender como é possível não haver contradição, tomemos o conceito de inteligência. O mundo natural é determinístico, mas não teleológico; o que quer dizer que quem determina a configuração dos objetos no tempo e espaço, se uma espécie é extinta ou não, não é a inteligência de algum ser, apesar de

1 Mas não deixou de fazer críticas pontuais a Charles Darwin, no tocante ao papel das emoções no gesto, conforme será explicado mais adiante. 
essa ilusão ser tão vívida. Nenhuma folha de uma árvore cai se não pela gravidade, independentemente de vontade ou intenção, e não se pode falar, a não ser cautelosamente, num sentido muito abstrato, de intenções nem de crenças.

De fato, todos os processos que transcorrem no mundo natural o fazem em conformidade com as leis naturais, o que não significa que não possam dar origem a sistemas de alta complexidade, deixando a impressão de haver uma inteligência por trás de si. Mas não é apenas a teoria da evolução em si que não é inteligente, como os primeiros organismos vivos a surgirem, e muitos ainda existentes, tais como plantas e fungos, não são inteligentes. Um indivíduo unicelular de uma espécie de alga ou plâncton tem uma relação muito limitada com o mundo que o rodeia, que se resume basicamente a reações físicas e químicas em seu meio interno, assim como é igualmente limitada a sua capacidade de reagir às menores mudanças ambientais em prol de sua sobrevivência. No entanto, conforme sistemas mais e mais complexos surgem, torna-se difícil e improdutivo usar do mesmo repertório conceitual, e os padrões que se repetem em alguns fenômenos só são percebidos assumindo uma perspectiva adequada (Pinker, 1998, p. 409).

A inteligência foi uma função complexa que surgiu do desenvolvimento do sistema nervoso em alguns animais em determinado momento da história evolutiva e manteve-se por ser uma vantagem competitiva para esses animais, assim como para alguns foi vantajoso o desenvolvimento de guelras ou trombas. Mead, porém, contrapondo-se à teoria das ciências naturais de Dimitrie Draghicescu (Joas, 1985, p. 91-92), considerava que o que faz o ser humano sui generis no reino animal, permitindo tratar a esfera das relações sociais com um repertório diferente daquele empregado nas ciências naturais, não é a inteligência propriamente dita, mas a maneira como objetos sociais e não sociais se apresenta aos observadores humanos.

Quando deixou Oberlin em 1883, os pais já falecidos, Mead passou por um período de dificuldades financeiras, afastado da carreira acadêmica, sustentando-se com trabalhos braçais, experiência que, conforme relatou em correspondência pessoal (Joas, 1985, p. 16), foi ao mesmo tempo árdua e enriquecedora, despertando seu interesse para os problemas concretos da vida social. Retornou à academia em 1887, na Universidade de Harvard, e passou um semestre estudando na Alemanha, durante o inverno de 1888-1889, país que era centro da psicologia social (Joas, 1985, p. 17-18), sua área de maior interesse.

A perspectiva psicossocial é necessária não apenas quando falamos de seres muito inteligentes, mas também de seres conscientes e que se desenvolveram como animais sociais, uma abordagem antropológica da consciência que Mead herdou de Wilhelm Wundt, um de seus mentores na Alemanha. É somente pela interação social com seus pares que essa consciência se consolida, interação que nos humanos, exclusivamente, se dá pelo emprego de signos, cujo estudo teve como um de seus pioneiros o fundador do pragmatismo, Charles Sanders Peirce, cujas teses Mead aprendeu indiretamente por um de seus mestres em Harvard, Josiah Royce, e aperfeiçoou lado a lado com seu colega e amigo John Dewey ${ }^{2}$.

2 Essa relação com seus herdeiros intelectuais será tratada com m mais detalhes na seção seguinte. 
Para Mead, a psicologia não precisa nem deve se desfazer da objetividade nem do rigor empírico e metodológico que usa ao tratar de outras perspectivas naturais, apesar de também não poder ser uma análise meramente mecanicista, correndo o risco de se perder de vista o que é o próprio objeto de estudo da psicologia. Tampouco pode ser solipsista, tratando a consciência como se esta pudesse existir em isolamento de outros. Isto é, a explicação de fenômenos mentais e comportamentos associados não é redutível a fenômenos não mentais, mas pode emergir destes.

\section{O GESTO E A ATITUDE}

O gesto é o conceito central para a psicologia social pragmatista de G. H. Mead. Os animais inteligentes, entre eles os seres humanos, aprendem com o ambiente, adaptam-se e reagem inteligentemente ao meio, de forma sensível ao contexto. Ao indivíduo, o tempo todo, chegam estímulos - visuais, auditivos, táteis -, e todos os objetos no universo são sujeitos às mesmas ondas sonoras, luzes, vibrações no solo... Mas os animais desenvolveram órgãos do sentido, receptores afinados a determinados estímulos, prontos a iniciarem uma reação eletroquímica, um sinal que viaja pelos nervos aferentes por meio do sistema nervoso central, em que sua transdução e seu processamento produzem um sinal que resulta em uma mudança de atitude e na subsequente resposta do indivíduo.

A inteligência confere ao animal a capacidade de reagir aos estímulos de que é rodeado, adaptando-se a eles por meio de um ato. Isso faz do gesto o que é. O gesto social, foco da obra de Mead, é aquele que o animal emprega a fim de modificar a atitude perante outro animal e se ajustar a ela $^{3}$, sendo aquele ao qual o ser humano se tornou particularmente adepto.

Mead emprega diversos exemplos de comportamento animal para exemplificar esse mecanismo mais simples de gesto. Em um de seus exemplos prediletos, a briga de cães, um cão começa a rosnar para outro. A visão do segundo é compreendida como ameaçadora pelo primeiro, engatilhando um processo que o leva a responder com o gesto de rosnar, na intenção de suscitar no segundo reação de medo, de luta ou fuga, e esse é o sentido do gesto, o que o cão pretende mudar no ambiente por meio do gesto.

O gesto provoca uma mudança não apenas no oponente, mas antes no primeiro cachorro: dentes à mostra, saliva, descarga de adrenalina que acelera seu batimento cardíaco. Ao mesmo tempo em que influencia uma forma externa, o animal opositor, o gesto interfere em formas interiores ${ }^{4}$, no corpo e na mente do primeiro cão. $\mathrm{O}$ segundo cão pode responder com um ataque, ou rosnando mais alto, uma conversa gestual. $\mathrm{O}$ desfecho de um ato social iniciado pelo gesto pode ser o princípio de outro gesto.

O ser humano também se engaja em conversas gestuais simples, sem linguagem, e o faz habitualmente: um motorista sinaliza com o pisca alerta sua

3 A tese defendida pelo autor é a de que todo gesto tem um fundo social.

4 O emprego do autor do termo forma é similar ao que hoje as ciências cognitivas chamam de módulos mentais e cerebrais, para designar elementos semiautônomos da mente ou de seu substrato físico. 
intenção de mudar para a faixa direita da pista. Então, realiza a mudança de faixa sem causar nenhum acidente. Nesse simples ato há o mais essencial em um gesto, a tríplice estrutura da qual surge o sentido (Mead, 1940, p. 268). O sentido do gesto nesse exemplo está, primeiramente, em sua relação com o motorista que inicia o ato desejado. Ao iniciar o gesto, ele estimula a própria mente a prosseguir $o$ ato, sabendo estar em segurança. Ao mesmo tempo, o gesto relaciona-se com o comportamento dos demais motoristas, que, ao perceberem a intenção do primeiro dando seta para a direita, mudam de atitude, respondendo com outros gestos, de deixar esse lado da pista livre. Finalmente, o processo relaciona-se com o desfecho (digamos, o resultado pragmático do ato) do motorista fazendo sua conversão sem colidir com outro veículo.

Sem as três relações, não se pode de fato falar de gesto. Uma criança pequena, negligentemente esquecida no carro pelo pai, que começa a brincar com a alavanca do pisca alerta, apesar de fazer algo fisicamente similar, não está realizando um ato que comunica sua intenção - o ato que deseja completar - nem para si nem para outrem (ela está sozinha no carro), até porque sequer há uma intenção ou um desfecho que mude a atitude do bebê $\hat{e}^{5}$, que também não sabe do significado por trás do pisca alerta. O gesto sempre implica uma interação em que há ajustes de conduta entre formas internas e externas (Mead, 1940, p. 71), mas, para ser gesto significante, é preciso ter uma ideia por trás, um sentido.

\section{A POSIÇÃO DE MEAD QUANTO AO BEHAVIORISMO}

Mead sempre tomou com respeito a psicologia behaviorista, mas não a vertente de seu conterrâneo J. B. Watson ${ }^{6}$, e sim principalmente a vertente do alemão W. M. Wundt, que conheceu nos anos em que estudou na Alemanha e do qual herdou o conceito de gesto (Mead, 1940, p. 13) e a importância da cultura no desenvolvimento do ser humano, considerando o trabalho de ambos um estágio necessário no desenvolvimento da psicologia como ciência e seu divórcio com os preceitos mentalistas de outrora (Mead, 1940, p. 21-23). Todavia, fez críticas bem pontuadas a esse paradigma behaviorista.

O filósofo julgou a psicologia behaviorista superficial demais, por se ater apenas ao comportamento físico do objeto de estudo, seja humano, seja animal, uma perspectiva sempre "da pele para fora", e limitando-se a fazer correlações entre estímulos que ocorrem ao sujeito durante uma experiência com as mudanças de comportamento observáveis subsequentes, paradigma conhecido como paralelismo, o qual, supostamente, seria demonstrado pela aquisição de fobias, mediante a associação de estímulos neutros e outros desagradáveis, conforme o experimento que o próprio Watson relatou ter realizado, em que uma fobia a ratos teria sido

5 E ainda que um adulto passe pelo estacionamento, note o pisca alerta e se desespere ao notar o bebê esquecido sozinho no carro, isso não seria uma relação simbólica, pois falta a intenção do agente.

6 Que também lecionou em Chicago, desde 1890. A rivalidade dos pensadores influenciou uma cisão do departamento de psicologia e filosofia, ficando Mead no de filosofia (Souza, 2011, p. 375). 
induzida em uma criança, assustando-a com um barulho ao mesmo tempo que um rato se aproximava. Além de excepcionalmente antiética, a conclusão à qual Watson chegou por esse experimento é duvidosa. O cientista cognitivista Steven Pinker (1998, p. 409), entre outros (Bisaccioni e Carvalho Neto, 2010), afirma serem todas as fobias relacionadas direta ou indiretamente a medos primitivos, não podendo ser induzidas com relação a objetos perfeitamente neutros, o que remete à ideia de impulsos ou instintos inerentes à natureza humana, instintos sociais, ideias que Mead adotou (com certa cautela) de William McDougall (Joas, 1985, p. 92-94).

$\mathrm{O}$ watsonismo, termo pejorativo usado por Mead para referir-se à vertente do behaviorismo de seu rival, reduzia a mente a uma série de reflexos condicionados, aprendidos pela repetição, desconsiderando quaisquer fenômenos subjetivos e simplificando excessivamente o esforço mental do indivíduo em interpretar sua situação (Mead, 1940, p. 101).

O problema começa quando se considera o tempo entre estímulo e resposta. Muito antes de o gesto começar - tornando-se facilmente observável - o sujeito inicia várias atitudes em preparação: antes de empurrar para cima o pisca alerta, o motorista solta alguns dedos do volante, move-os para mais perto da alavanca do pisca alerta, pousa um ou dois dedos na alavanca... Antes mesmo de soltar a mão do volante, ele precisa ter ideia de aonde quer chegar e como fazê-lo e ter noção de como fazê-lo com segurança, por exemplo, de quais gestos precisa desempenhar para que os demais motoristas, cada um em seu próprio trajeto, o permitam seguir o seu, e nenhuma dessas fases do ato faz sentido sem tratar a ação como gestos que são reflexo de atitudes, assim como também não faz sentido sem levar em conta que tais gestos são fases de um ato social.

O behaviorismo watsoniano pode explicar por que o motorista dá seta para a direita, mas não por que ele resolveu dirigir de sua casa, em Campinas (SP), até a Avenida Paulista. O planejamento fica difícil de prever-se assim, como exposto. Dewey (1896 apud Joas, 1985, p. 66) argumentou que considerar como elementos isolados o estímulo, o processamento e a resposta - o conceito de arco reflexo - demonstra mera causalidade, correlação temporal e não causal, o que coloca equivocadamente a mente do sujeito como entidade passiva, como se suas preconcepções e expectativas preexistentes não determinassem as respostas, ou como se os estímulos aos quais se atenta e reage não fossem previamente selecionados pelo mecanismo de atenção.

Além da orientação à ação, a metodologia foi o que mais interessou Mead, outra faceta do naturalismo: o behaviorismo propõe-se a afastar complicaçóes metafísicas (termo de Mead) na análise científica do sujeito, uma visão objetiva em terceira pessoa, e levando em conta apenas o que pode ser aferido em terceira pessoa, excluindo termos vagos que dizem respeito a fenômenos irremediavelmente subjetivos, tais como sentimentos, sonhos, pulsões, traumas, dos quais correntes de pensamento europeias, como a fenomenologia e a psicanálise, estavam repletas. Para os behavioristas, aquilo que é oriundo da introspecção (do psicólogo ou de seu objeto de estudo) e que parte da noção cartesiana de mente e corpo fica de fora da análise. A mente é sempre entendida como um resultado do processo evolutivo, em que alguns reflexos mais vantajosos para a sobrevivência prevaleceram, dispensando um fantasma na máquina para explicá-la. 
Perspectiva, como colocou o filósofo funcionalista contemporâneo Daniel Dennett (1995, p. 80-83), não é uma questão de negar a existência de elementos menores em um sistema, que possuem sua realidade própria, nem de dizer que o sistema maior possui alguma existência metafísica, mas de abstraí-los para fins de estudo, de encontrar padrões que possibilitam compreender e prever o comportamento do sistema, tal como se pode estudar o trânsito de uma cidade ignorando os detalhes de como funciona um motor à combustão, e o fenômeno é mais bem compreendido do topo de um prédio alto do que do meio de uma rua congestionada. Da mesma forma, a mente e seus fenômenos são tão reais quanto seu substrato orgânico, o cérebro, devendo ser estudados sem reducionismos.

Essa perspectiva materialista foi adotada por $\mathrm{Mead}^{7}$, mas julgando-a, no entanto, pecar pelo excesso, resultando em uma análise superficial e individualista demais, dando muito pouca importância tanto ao meio social como à reflexividade do self, da sua própria consciência.

No que se refere a Wundt, Mead estimava-o muito mais. O conceito de gesto do psicólogo alemão e sua teoria linguística que se baseava na sua psicologia social Volkerpsychologie foram um importante alicerce para o pensamento de Mead, que no começo de sua carreira os tomava praticamente de forma acrítica, em seu primeiro ensaio sobre a Völkerpsychologie (Joas, 1985, p. 94-96).

Mas seu pensamento divergia de Wundt em aspectos importantes. Em seu segundo ensaio sobre o tema, Mead julgava que o conceito de apercepção de Wundt pouco diferia do paralelismo em seu entendimento da intersubjetividade, baseando-se demais no conceito de imitação (esse problema será explorado com mais detalhes na próxima seção), sem tampouco dar conta da inteligência que intermedeia o estímulo e a resposta, lacuna que o americano viria a preencher com o interacionismo simbólico.

Quanto à intersubjetividade, sem desmerecer Wundt, pioneiro desse paradigma da psicologia científica, Mead apontava como problema de sua Volkerpsychologie (Mead, 1940, p. 49-50) basear-se no pressuposto de que o self e a mente existem $a$ priori, em um hipotético primeiro estágio mental solipsista na formação do indivíduo, até ser lapidados por interações sociais conseguintes. A diferença, para Mead, é a interação social que precede a consciência, e o self só passa a existir a partir desta, e não desde o nascimento do indivíduo (Mead, 1940, p. 49).

A questão do valor da perspectiva subjetiva no entendimento da mente humana - talvez, o principal motivo da cisma da filosofia analítica e continental, e mesmo da filosofia analítica, que prima pela precisão na escolha de termos e pela objetividade e clareza na exposição de ideias — se vê, até os dias de hoje, como um ponto mal resolvido: quão confiáveis são os relatos subjetivos se são as experiências subjetivas providas de propriedades - sintetizadas pelo termo qualia ${ }^{8}$ — que tornam a experiência subjetiva irremediavelmente privada e inefável, apensando a dúvida

7 Distanciando-o consideravelmente do pensamento do pragmatista William James.

8 Cunhado por Peirce ainda no século XIX, tornou-se mais evidente nos anos de 1980 e 1990, com os avanços das ciências cognitivas e a aproximação do debate entre filósofos e neurocientistas. 
por trás da indagação "Como sei que meu vermelho é igual ao seu vermelho?". Sobre esses dilemas, às vezes, mesmo os filósofos mais proeminentes parecem debater sem dar pistas de estarem falando da mesma coisa9.

Esquivando-se de temas metafísicos, a proposta de Mead foi fazer uma análise do comportamento levando em consideração também os elementos internos, as formas, a dinâmica de sua interação, bem como sua interação com a sociedade em que se encontrava. Seu entendimento de subjetividade advém da reflexividade, do ver o outro em si mesmo, elementos que tornam a mente do ser humano peculiar no mundo animal, mas os paralelos com o comportamento animal são úteis, e Mead valia-se deles constantemente, ainda que não haja algo de muito diferente nos gestos dos animais (mesmo que sejam, efetivamente, gestos), a começar por sua aprendizagem.

\section{COMPORTAMENTOS HUMANO E ANIMAL}

Os animais nascem com várias predisposições à interação gestual, assim como com aptidão a aprender novos gestos, novas associações. Uma explicação comum tanto nos tempos de Mead quanto no presente - é que os animais simplesmente aprendem por imitação, conforme o provérbio de língua inglesa monkey sees, monkey does ("macaco vê, macaco faz"). Mas Mead refutava tal explicação: a imitação é pouco prevalente no mundo animal, apesar de ser mais comum nos seres humanos (Mead, 1940, p. 51).

Digamos que um papagaio aprenda a cantar uma melodia, um jingle repetido na televisão de seu dono. Ele não está tentando imitar a televisão. O papagaio gosta da melodia. Um estímulo provido por uma forma externa provoca uma reação no papagaio, e ele passa a reproduzir sons, com o próprio aparato vocal, até que seja capaz de reproduzir o som que lhe agrada. A ave precisa repetir algumas vezes e sabe que foi bem-sucedida quando o mesmo estímulo que produz provoca a resposta produzida pela televisão. Não há uma identificação que leva à imitação, mas um ajuste adaptativo do comportamento do sujeito. Nesse caso, tanto faz se o que provocou o primeiro estímulo foi outro papagaio, uma ave de outra espécie, ou um pardal imitando um canário sem nem saber que está imitando um canário, no original de Mead (Mead, 1940, p. 66), ou um objeto eletrônico.

Um caso apenas superficialmente parecido com o do papagaio - e um exemplo melhor de imitação - é o de um estudante brasileiro tentando aprender inglês. Em uma aula, ele tenta aprender a pronunciar o fonema $\theta$, uma das formas de pronunciar o dígrafo th, particularmente difícil para os falantes de língua portuguesa. Ele ouve e vê o professor pronunciando thing, tenta dizer thing da melhor forma que consegue, mas o professor não fica satisfeito, repete thing, e o aluno, atentando-se ao som da palavra e ao movimento dos lábios de seu professor, tenta novamente e pronuncia um pouco melhor.

Há, nessa atividade, algo mais do que aprendizagem por assimilação de estímulo, algo que Mead considerava não existir nos animais - ao menos não de

9 Como explicitado pelo infrutífero debate entre John Searle e Dennett (Searle e Dennett, 1995). 
maneira tão sofisticada quanto no humano - , que é a identificação com o outro e a compreensão das atitudes do outro comparadas às próprias (Mead, 1940, p. 67). $\mathrm{O}$ aluno entende que é um ser da mesma espécie que o professor, com o mesmo aparato vocal e (em certa medida) o mesmo aparato cognitivo. Ele não apenas aprende a dizer thing, mas a usar a palavra thing, e só aprende quando essa palavra passa a ter em si a mesma utilidade que tem para o professor para compor gestos vocais, que pode utilizá-los para influenciar outros indivíduos e ajustar sua conduta.

\section{DO GESTO AO SIGNO}

No gesto vocal, uma de suas três estruturas, a relação do gesto com o próprio falante importa mais do que em gestos simples (não simbólicos), uma peculiaridade da espécie humana, sendo também digno de nota o planejamento por trás desse gesto, baseado na tomada de perspectiva. $\mathrm{O}$ rosnar de um cachorro para outro não causa nem, necessariamente, já causou medo no próprio cão que rosna como causa no segundo, tampouco depende de o primeiro cachorro compreender seu par e colocar-se no ponto de vista dele. Trata-se de apenas um gesto instintivo sem deliberação (Mead, 1940, p. 63).

Mead poderia dizer do papagaio que aprende a cantar o jingle da TV, de abelhas de uma colmeia buscando néctar para fazer mel, e mesmo de seres humanos em diversas situações em que a resposta automática e irrefletida é necessária (Mead,1940, p. 178-179), como soldados combatendo numa guerra, obedecendo a um rígido treinamento, ou funcionários em uma estereotípica linha de produção de modelo fordista. Mas a inequívoca idiossincrasia do comportamento social humano é resultado de sua capacidade para a mediação simbólica, que o permite planejar ações para o futuro com muito mais antecedência e realizá-las com precisão, uma prática que depende do reconhecimento do outro e cuja aprendizagem depende, implicitamente, de tal reconhecimento, e não da mera repetição (Mead, 1940, p. 118-119).

Por essa faculdade do cérebro humano, sua capacidade de manipular símbolos abstratos e planejar, é tão difícil para os humanos entenderem o que se passa na mente dos animais, uma frustração que todo dono de animal de estimação já sentiu e um problema filosófico que vem à tona sempre que se debatem questões de direitos dos animais.

Esse problema também foi abordado pelo filósofo Thomas Nagel (2015), em seu ensaio "Como é ser um morcego?", no qual o autor demonstra a dificuldade de se colocar na perspectiva de um animal e de fato saber como é ser uma criatura com uma estrutura cognitiva tão diferente.

\section{SIGNO E SÍMBOLO}

A definição de G. H. Mead de signo e sua abordagem da semiótica, no geral, é próxima das de Peirce, também triárquicas: "Eu defino signo como qualquer coisa que seja assim determinada por outra coisa, chamada seu Objeto, e assim determina seu efeito sobre uma pessoa, efeito este que eu chamo seu Interpretante, de tal forma que este determina aquele" (Peirce, 1893-1913 apud Atkin, 2013, § 1, tradução nossa). 
Podem-se tomar as citações bibliográficas, como as deste trabalho, como um exemplo de signo, conforme foi definido resumidamente por Peirce na citação anterior. O par de parênteses contendo a primeira letra maiúscula e quatro numerais têm como seu objeto a bibliografia deste trabalho, o que significa que ela determina o signo. Simultaneamente, o efeito causado no leitor - olhar para as páginas finais e ler o que está escrito - é seu interpretante ${ }^{10}$. Interpretante não é o indivíduo como um todo que capta o signo, mas aquilo que Mead denominou de forma interior e, mais especificamente, a forma interior quando o signo está sendo interpretado, num sentido abstrato - na mente do leitor quando visualiza e traduz o par de parênteses contendo uma palavra com a primeira letra maiúscula e um número de quatro dígitos (ou do motorista que vislumbra o pisca alerta do carro à sua frente).

As citações possuem diversas características, e cada uma continuaria sendo signo, mesmo se algumas delas fossem diferentes: poderiam estar na cor azul, em outra fonte, impressas ou exibidas na tela de um computador, mas apenas algumas de suas características são importantes (estar entre parênteses, conter primeira letra maiúscula e números...), pois somente elas determinam as condições para o nexo causal entre objeto e signo e entre signo e interpretante. $O$ conjunto dessas características definidoras do signo pode ser chamado veiculo do signo, representação, representamen, entre outros sinônimos (Atkin, 2013) e normalmente é referido apenas como signo por Peirce.

O signo pode ser ícone, índice ou símbolo (Santaella, 1983, p. 13; Atkin, 2013). Um ícone é meramente um objeto que se assemelha a outro, tal como uma fotografia, e um índice possui alguma relação sensorial ou causal — uma história em comum - que não sua semelhança. Nessas categorias se encaixam as associações simples de estímulo e resposta que interessam ao behaviorismo e que a mente de um animal não humano é capaz de fazer.

Mead, principalmente considerando sua teoria tal como apresentada em Self, mind, and society ${ }^{11}$, sempre retomava a perspectiva biológica para tratar das relações semânticas, tomando como base o pouco conhecimento que se tinha em sua época sobre a estrutura e o funcionamento do sistema nervoso ${ }^{12}$, mas com o qual estava bem familiarizado, cujo papel era enviar estímulos eletroquímicos dos órgãos dos sentidos e do interior do organismo em direção ao sistema nervoso central, provocando sensações.

O filósofo também sabia que determinadas conexões sinápticas entre neurônios podem reforçar-se conforme são ativadas, delineando trilhas de neurônios com maior tendência a dispararem um em resposta ao outro, o mecanismo de reforço sináptico, que no século XX seria sintetizado na frase neurons that fire together wire

10 Não o ato em si, mas o efeito produzido em sua mente que eventualmente leva ao ato, em Peirce.

11 Sobre a qual, apesar de não se negar seu valor, pesam críticas. Ver: Joas e Huebner (2016).

12 O neurônio, com sua estrutura molecular arbórea, composto de dendritos e axônios, foi identificado pela primeira vez em 1897, pelo histologista espanhol Santiago Ramón y Cajal, alguns anos após Mead começar a lecionar na Universidade de Chicago. 
together ("neurônios que disparam juntos se conectam"). Os reflexos simples, que todos os animais desempenham e são capazes de aprender por rotinas de repetição, e cujos estímulos entrariam nas categorias que Peirce denominou de ícones e índices, são mais facilmente explicáveis pela perspectiva biológica.

Quando começamos a tratar de símbolos propriamente ditos, cuja associação precisa ser aprendida, e que podem ser empregados em uma diversidade de situações diferentes, requer-se uma explicação mais aprimorada. As palavras são um símbolo significante, estímulos que não parecem em nada com o seu referente, nem possuem nexo existencial com ele, mas que precisam ser aprendidas.

\section{ATENÇÃO E APRENDIZAGEM}

William James (1918, p. 403), no capítulo IX de seu clássico Principles of Psychology, ressaltou o fato de como, dos "milhões de itens exteriores" presentes em seus sentidos, poucos chegam à sua consciência, pelo simples motivo de não ter interesse por eles. Mead, por sua vez, detectou como a percepção é um movimento que parte de um ato em andamento, mas implica a interrupção momentânea desse ato para contemplar opções de continuidade, mantendo-se integrada ao fluxo gestual, sendo um ato de percepção, como a visão, uma sequência coordenada de movimento dos olhos, ajuste de foco das pupilas e coordenação desse movimento complicado para trazer à luz aquilo que se mira para o centro da retina (Joas, 1985, p. 149).

Essa compreensão de que a percepção nunca é imediata, mas sempre mediada, é respaldada pela moderna ciência cognitiva. Quando a torrente de sinais sensoriais converge no tálamo, logo passa por um primeiro processo de filtragem que separa sinal e ruído, e o tálamo encaminha os estímulos de cada modalidade para seus respectivos córtices (Sternberg e Sternberg, 2016, p. 34), caso dos estímulos visuais advindos dos nervos ópticos, que convergem no quiasma óptico, dali para o tálamo, e onde chegam invertidos (o sinal do olho esquerdo para o hemisfério direito e vice-versa) ao córtex visual primário $(\mathrm{V} 1)^{13}$, em que há conjuntos de neurônios especializados em reconhecer cores (V4), formas, luminosidade (V1) e que são ativados por determinados padrões, como linhas, vértices e intersecções. Do córtex visual primário saem duas vias, uma ventral, ligada aos lobos temporais, na qual é interpretado o que está sendo visto, e uma via dorsal, em direção ao córtex parietal, preocupada em localizar espacialmente o objeto (Dehaene et al., 2006; Sternberg e Sternberg, 2016).

Também os córtices dos lobos temporais são responsáveis por interpretar e contextualizar os estímulos auditivos, sejam sons sem significado, sejam palavras ou frases com sentido. Essas regiões do cérebro, localizadas, como o nome sugere, nas têmporas, abrigam em sua parte mais interna as amígdalas, organelas em formato e tamanho de ervilha que, sintonizadas ao processamento simbólico executado nos córtices do lobo temporal, dão entonação emocional correspondente às situações compreendidas e influenciam na tomada de decisões e no estado de atenção a um ou outro estímulo (Damásio, 2009, p. 35-36).

13 No lobo occipital, parte mais anterior do cérebro, atrás da nuca. 
O córtex pré-frontal, essa porção do lobo frontal mais anterior, logo atrás da testa, é repleto de neurônios piramidais, concentrados principalmente na superfície mais exterior do encéfalo, que são ricos em dendritos, receptores sintonizados à atividade do restante do cérebro, e axônios que enervam o restante do córtex e do subcórtex, como edifícios administrativos equipados com muitas antenas, que coordenam a atividade do restante do organismo. Como explica Antônio Damásio, neurocientista e filósofo - naturalista e estudioso de Baruch de Spinoza, como Mead também o foi -, as estruturas primárias préencefálicas fazem mapas que correspondem ao estado atual do corpo, à sua homeostase. Trata-se da primeira representação, chamada pelo autor português de protoself ${ }^{4}$, enquanto as estruturas corticais que codificam símbolos trabalham de forma a propiciar a manutenção dessa homeostase, compreender adequadamente contexto e oportunidades futuras e recordar-se de eventos passados, eventos que, como Damásio (2009, p. 83-86) defende, sempre são memorizados com o estado emocional relativo, mais bem ilustrado pelo diagrama da Figura 1.

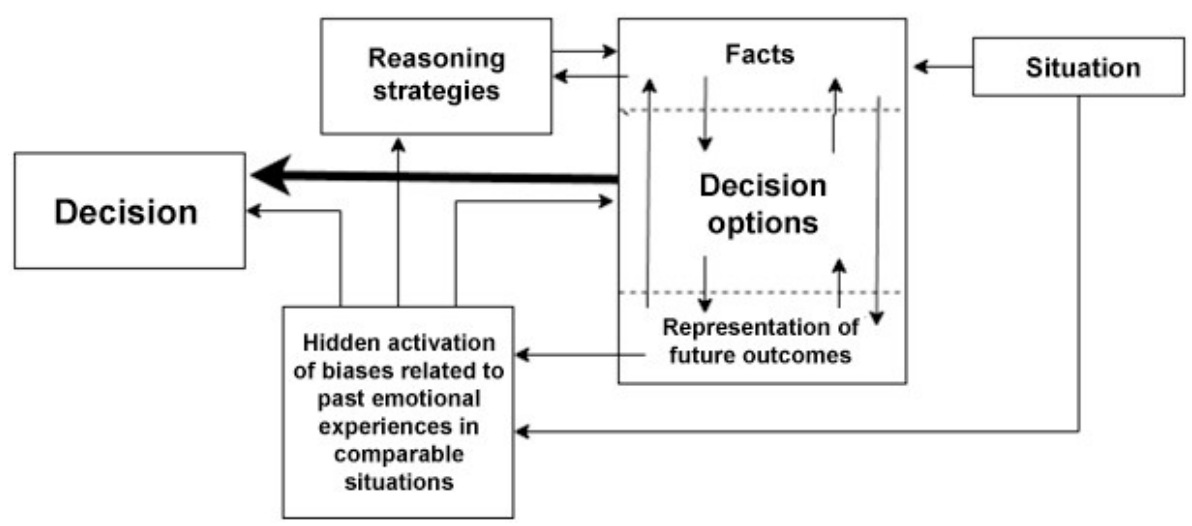

Fonte: Elaborado pelos autores, reproduzido fielmente do livro Em busca de Espinosa (Damásio, 2009, p. 86).

Figura 1 - Fluxo de tomada de decisões.

O modelo é muito similar ao de ação em quatro fases proposto por Mead, nesta ordem: impulso à ação, percepção, manipulação e consumação (Joas, 1985, p. 148-149). O impulso à ação pode ser entendido como a predisposição em que o indivíduo se encontra antes mesmo de deparar com uma nova situação ou que o leva a ela, podendo ser ou não consciente e influenciar em sua percepção. A lembrança do que já lhe ocorreu antes, organizada em signos e símbolos mentais, bem como a lembrança de quão boas ou ruins foram determinada situação e sua decisão, influi diretamente no que Mead designou por manipulação, processo ilustrado na caixa maior do diagrama, e tal lembrança estruturada, auxiliada pelo raciocínio, intermedia a consumação perante um novo episódio.

14 Mead protestaria quanto a essa escolha de palavras! 
Os pragmatistas, incluindo Mead, estavam no caminho certo ao considerar um arco orgânico, em que o ato é constituído de diversos módulos que interagem dinamicamente, um determinando o outro, e a compreensão de sentido como um processo de mão dupla. Dado que é tão bem conhecido o papel do córtex pré-frontal para a atenção e o aprendizado, bem como a importância do neuromodulador dopamina para o funcionamento eficiente desse córtex, é espúria a militância ao uso de psicoestimulantes ${ }^{15}$ para crianças e adolescentes com dificuldades patológicas em manter a atenção durante as aulas e permanecerem quietos. Uma crítica infundada, pretensamente contra uma suposta medicalização da vida, mas que quase sempre carrega preconceitos e opiniões vulgares quanto ao que seria o real problema ("falta de vergonha na cara", "isso no meu tempo se resolvia na palmada"). Um preconceito cujo fundo é o dualismo cartesiano, a ideia de que há algo de etéreo e quase sobrenatural nos fenômenos mentais.

Mas seria igualmente espúrio dizer que um transtorno biológico é a única explicação possível quando há problemas de disciplina ou desmotivação por parte do educando. No que tange à atenção, Mead acerta precisamente ao descrever o homem como um animal atento, cuja atenção pode ser direcionada aos estímulos mais sutis (Mead, 1940, p. 25). A isso se confere a sua capacidade de entender a importância do estímulo e redirecionar seu aparato neurocognitivo para tal estímulo.

$\mathrm{O}$ aluno que tenta aprender a pronunciar o fonema $\theta$ - e este exemplo pode ser extrapolado para qualquer outra relação de ensino - não precisa apenas reconhecer no professor um igual, mas também compreender a relevância da atividade. Se não consegue se concentrar nessa atividade, ou ignora o professor, prefere olhar a janela, isso pode ser por não se interessar pelo assunto, não ser capaz de vislumbrar a importância que o aprendizado da língua inglesa pode ter em seu futuro. A falta de perspectiva que alimenta a falta de motivação - mesmo entre alunos sem nenhum transtorno neurológico - não é incomum nas escolas.

A esse raciocínio, segue a pergunta: como decidimos que tipo de conhecimento é útil? $\mathrm{E}$ a veracidade daquilo que se ensina pode ser qualificada como um valor em si mesmo? $\mathrm{Ou}$, ainda, o que faz verdadeiro um conhecimento? Este último problema, de maneira especial, preocupou muito o filósofo austríaco Ludwig Wittgenstein.

\section{LINGUAGEM E CONTEXTO}

Em seu Tractatus logicophilosophicus, Ludwig Wittgenstein (2001, p. 165) escreveu:

O homem possui a capacidade de construir linguagens com as quais se pode exprimir todo sentido, sem fazer ideia de como e do que cada palavra significa - como também falamos sem saber como se produzem os sons particulares.

A linguagem corrente é parte do organismo humano, e não é menos complicada do que ele.

15 De maneira especial a Ritalina, nome comercial do metilfenidato, mais usada para Transtornos do Déficit de Atenção e Hiperatividade (TDAH). 
É humanamente impossível extrair dela, de modo imediato, a lógica da linguagem. A linguagem é um traje que disfarça o pensamento. E, na verdade, de um modo tal que não se pode inferir, da forma exterior do traje, a forma do pensamento trajado; isso porque a forma exterior do traje foi constituída segundo fins inteiramente diferentes de tornar reconhecível a forma do corpo.

Os acordos tácitos que permitem o entendimento da linguagem corrente são enormemente complicados.

Por mais diferente que seja o pensamento de G. H. Mead em relação ao do filósofo austríaco citado na epígrafe desta seção, de uma geração posterior e da tradição analítica, não é difícil notar as semelhanças nesse trecho de seu Tractatus: a admissão da complexidade da linguagem, bem como a impossibilidade de extrair imediatamente sua lógica, e implicitamente a admissão da "aptidão sem conhecimento" usada pelas pessoas. Apesar de nem todas as comunidades humanas terem desenvolvido ou adotado a linguagem escrita, nenhuma delas era muda. A maior parte da população mundial era analfabeta até meados do século $\mathrm{XX}$, mas quase toda a população mundial sempre soube falar e ouvir, ainda que jamais houvesse frequentado uma aula de gramática. Também se verificam, no entanto, divergências importantes entre Mead e Wittgenstein de Tractatus, e uma delas é a suposição de que linguagens são criadas.

O programa pragmatista de ancorar a realidade dos fatos em suas consequências práticas leva ao entendimento de que a linguagem é um fenômeno humano e social. Wittgenstein, cuja preocupação e cujo papel que colocou à filosofia se distinguem daqueles dos pragmatistas, admitiu que não existe linguagem solitária. Não só as linguagens são aprendidas por meio de interações sociais, como são imprescindíveis para a própria cognição introspectiva.

A multiplicidade de resultados pragmáticos que uma palavra ou um encadeamento de palavras pode provocar em pessoas diferentes, à primeira vista, parece um desafio ao pragmatismo. Por exemplo, a palavra cigarro pode significar morte, doença ou desperdício de dinheiro para um não fumante que a ouve em uma conversa de corredor, quando um dos participantes sugere ir para a área de fumantes, e não muda nada em sua atitude, respondendo apenas: "Não, obrigado. Vou ficar por aqui mesmo". Ao mesmo tempo que para outro fumante que participa da mesma conversa cigarro significa algo desejável, causando uma mudança de atitude e de conduta. Ele vai embora e segue o enunciador da proposta em direção a uma área aberta.

Wittgenstein denotava esse tipo de interação como “jogos de linguagem”, e, apesar de provavelmente não ter tido contato com o pensamento de Mead ou Dewey diretamente (mas com James, sim, conforme Haack, 1982), nota-se que seu enfoque nos problemas da linguagem e sua preocupação em desfazer mal-entendidos são, até certo ponto, pragmáticos. Mas, antes de tratar mais de Wittgenstein, é preciso falar das origens do ramo da filosofia do qual fez parte, um que se desenvolveu paralelamente ao pragmatismo, mas contém semelhanças notáveis. 


\section{O PRIMEIRO E O SEGUNDO WITTGENSTEIN}

Para Wittgenstein (2001, p. 135), em seu Tractatus, “o mundo é a totalidade dos fatos, não das coisas", e um fato consiste na configuração das coisas. Coisas - ou objetos — são simples (Wittgenstein,2001,p.139), e a forma como se relacionam, entrelaçando-se como os elos de uma corrente, é sua estrutura lógica do estado de coisas, e a estrutura dos fatos - cuja totalidade é o mundo - constitui o estado de coisas (Wittgenstein, 2001, p. 141).

Acredita-se que a epifania que Wittgenstein tenha tido e sua inspiração para escrever o Tractatus tenham sido um artigo de revista (Costa, 2002, p. 24-27) descrevendo - ou figurando - um acidente de trânsito, em primeiro lugar com uma maquete, depois com uma descrição verbal. $\mathrm{O}$ que o acidente, a maquete e o texto têm em comum? Quando fazemos uma afirmação sobre algum fato no mundo, fazemos uma figuração, que é um modelo de realidade (Wittgenstein, 2001, p. 143), e por trás dessa figuração - que a traja — está uma proposição. Uma proposição é uma representação de um fato do mundo, imitando sua forma lógica, em uma relação isomórfica, dos elementos da proposição com os objetos do mundo. Uma proposição pode, no entanto, existir apenas como forma lógica, sem correspondente no mundo real, e pode afirmar categoricamente aquilo que não é o caso.

Nota-se que a preocupação de Wittgenstein no Tractatus é estabelecer a lógica dos predicados e como determinar sua validade, mas pouco diz sobre como provar de forma definitiva a verdade de figurações e proposições, como sabermos se uma proposição corresponde a um fato no mundo concreto, e essa tarefa parece impossível apenas levando em conta sua extensão.

Wittgenstein baseou-se no atomismo lógico de seu mentor Edmund Russell, mas foi mais cético quanto ao poder da análise lógica, pontuando que a figuração pode ou não representar a realidade e somente comparando-a com a realidade podemos verificar se seu sentido - o que ela representa - é verdadeiro. Porém como comparar, para saber se estamos ouvindo uma sentença verdadeira e não uma mentira ou uma peça de ficção?

Muito se engana o leitor desavisado que, ao ler o Tractatus e deparar com a maneira aparentemente simplista como o autor procura - assumidamente - resolver os problemas da filosofia trabalhando puramente com a lógica da linguagem, tal como seus antecessores, chega à conclusão de que se trata de um arquetípico filósofo em sua proverbial torre de marfim. Além do Tractatus, Wittgenstein escreveu outro livro, publicado postumamente (a seu pedido), intitulado Investigações filosóficas, em que faz várias correções e questionamentos revalorizando a linguagem natural e assumindo uma postura muito mais próxima do naturalismo e do próprio pragmatismo, como aponta o filósofo Robin Haack.

Ao lançar o conceito de jogo de palavras, Wittgenstein aceitou a importância do contexto para determinar o sentido de uma proposição. Contexto, como escreveu Dewey, é um "corpo de crenças e instituições, e as práticas aliadas a elas" (Dewey, 1969, p. 106 apud Haack, 1982, p. 106).

Reconhecia a relevância do comportamento para compreender adequadamente o sentido: como o efeito que proposições exercem sobre os interlocutores 
depende de como entendem o conceito e, sobretudo, a importância de todos os interlocutores concordarem em "jogar o mesmo jogo". A diferença crucial, como aponta Haack, está no papel que Wittgenstein prescreveu aos filósofos. Para ele, a filosofia não deveria servir à ciência, tampouco os filósofos deveriam intervir com seu trabalho no funcionamento da sociedade, o que é radicalmente contra o programa pragmatista. Apesar da importância incontestável desse austríaco para o pensamento ocidental do século XX, mesmo os filósofos da analítica de hoje discordam quanto a tal indiferença: quem faz seu papel esclarecendo ideias e dissolvendo problemas deve não apenas esperar, como também assumir a responsabilidade por suas repercussões, além de servir de exemplo aos ouvintes. Essa responsabilidade tem como alicerce a aproximação da verdade, mesmo esta não sendo única nem estando contida numa única mente.

Para Mead, de forma similar, a verdade e seu caráter universal não se encontram na mente de um único indivíduo nem podem ser entendidos de modo puramente abstrato, desconsiderando o contexto social. Eles estão inseridos em um mundo comum (Joas, 1985, p. 75). No entanto, ao se tratar de verdade e objetividade, é preciso tomar cuidado para não incorrer em um erro muito comum e pernicioso.

\section{OBJETIVIDADE E A ARMADILHA DO RELATIVISMO}

O debate sobre educação no Brasil está num entrave, e não por falta de tentativa em prol de sua progressão. São inúmeros os debates dentro e fora do meio acadêmico. Nas conversas de especialistas em painéis nos canais de TV, bem como nas truculentas discussões de leigos em redes sociais, nunca se chega a nenhum acordo, e algumas palavras são sempre ouvidas e repetidas ad nauseam: ideologia, doutrinação. De um lado, afirma-se que o papel da escola é só ensinar, e ensinar consiste apenas em passar conhecimento, abstendo-se de opiniões pessoais. Do outro, reafirma-se a dificuldade de separar o que é ensinar do que é opinar, a importância da pluralidade de ideias, e defende-se o papel social da escola, às vezes apontando o próprio conceito de passar conhecimento como algo obsoleto ou simplesmente uma tarefa distinta. Muita polêmica estéril, no meio da qual, por fim, alguém propõe um remédio que de fato é um veneno: a postura relativista, moral e epistemológica, com frequência associada a uma tradição pouco coesa, normalmente designada pelo termo guarda-chuva "pós-modernismo" (Glock, 2008, p. 232).

A postura relativista é errada, em primeiro lugar, por ser impossível de defendê-la sem necessariamente entrar em contradição. Se a verdade não existe, ou ainda, em uma variação solipsista, "cada um tem sua verdade", nenhum conhecimento é superior a outro e tudo o que se ensina dentro e fora das escolas é opinião, ou mera construção social - o que por si só é uma afirmação que se pretende verdadeira. Se por um lado, como se procurou demonstrar na seção anterior, somente a lógica não é suficiente para fazer uma afirmação verdadeira (não apenas internamente consistente ou cognoscível), sem a lógica é impossível. Não é necessário nem desejável adotar a postura relativista ou contrapor o papel social da escola ao seu papel de aprendizagem - não se nos atentarmos a Mead, assim como a Dewey e aos pragmatistas de seu tempo, mas não necessariamente os posteriores. 
Voltando à análise de Joas (1985, p. 145-146), a conciliação entre sua convicção no pragmatismo e sua intersubjetividade para a construção do self não foram tarefas fáceis, mas uma atingiu sucesso ao final de sua trajetória, tendo afastado desde o início as convicções paralelistas, de que estados de consciência são uma representação estática — ou isomórfica — da realidade, mas sim um fluxo de sinais sendo roteados por meio de diversos nódulos no sistema nervoso, num processo contínuo de percepção e várias fixações de conteúdo. O perigo oposto ao relativismo - o do realismo ingênuo, positivista - passou longe de Mead, tanto quanto estava distante a noção de um self perfeitamente demarcado do exterior ou até do próprio corpo, a ilusão cartesiana.

Para Mead, o conceito de verdade tem íntima ligação com a própria construção do self. Pelo interacionismo simbólico, seres humanos compartilham conhecimentos, estruturados em símbolos que indexam conjuntos de sensações e reações. O desfecho de alguns gestos se torna consensual, e os objetos que manipulamos, bem como aqueles que construímos, têm seu significado unânime baseado na utilidade que oferecem a nossos gestos. Para tomar um exemplo, quando os defensores do porte de armas dizem que "armas não matam pessoas, pessoas matam pessoas", estritamente falando, eles estão certos, no entanto a sugestão que fica subentendida, de que armas são apenas objetos perfeitamente neutros e que não faz sentido regulamentar sua posse, seu porte nem seu comércio, está completamente equivocada. São chamadas armas, em primeiro lugar, pois são entendidas como objetos feitos sobretudo para matar, projetadas e fabricadas de forma a facilitar a consumação desse ato da maneira mais eficiente possível.

\section{CONSIDERAÇÕES FINAIS: MEAD E A EDUCAÇÃO ESCOLAR}

Existem entendimentos acerca de nomes e conceitos - símbolos — que se tornam universais em prol de sua aplicação efetiva na organização das atitudes de indivíduos em atos sociais, o que só é possível quando o símbolo é universalmente aceito (Mead, 1940, p. 146). Na escola, quando certas condições estão satisfeitas, a criança é introduzida nesse universo conceitual, anterior a ela, o que se dá pela atividade de ouvir as palavras do professor e ler o que escreve na lousa, assimilando os símbolos que a ajudarão a interagir num mundo comum, a cultura. $\mathrm{Ou}$, como expressou Cledes Antonio Casagrande (2014, p. 97):

O modelo de ação e de racionalidade intuído por Mead se liga à necessidade concreta de resolução dos problemas quotidianos que emergem na vida da comunidade no nível da cultura, da vida prática e da vida material. Nesse cenário, a educação emerge como uma resposta organizada da comunidade à questão de como ensinar aos seus novos membros o modo mais adequado para a resolução dos problemas concretos das diversas dimensões da vida.

Ao receber essas novas informações, a criança não está apenas acrescentando novas habilidades ao seu self, mas sim, efetivamente, formando-o, ao expandir a possibilidade de realizar atividades diferentes — aprendendo matemática, ela 
ganha maior autonomia em gastar ou poupar sua mesada; aprendendo a ler e escrever, pode expandir ainda mais seu repertório mental com livros ou, como é o caso de muitas crianças, dar início à leitura por meio de quadrinhos. Ao conhecer situações diferentes, por signos de pessoas que não conhece, a mente dessa criança vai tornando-se cada vez menos restrita à realidade limitada de sua escola, de sua família e de sua comunidade e mais familiarizada com a cultura do mundo, pelas palavras de pessoas distantes, pelo signo e por partilhar de uma natureza humana que subsiste a todos, crescendo mais do que poderia se estivesse presa ao leque limitado de informações familiares de sua realidade imediata.

Quando pensamos em papel social da escola, há que se manter em mente que o papel tradicional da escola também é social: quanto melhor é desempenhado, maior seu sucesso em formar indivíduos competentes e autônomos para viver em sociedade, não sendo um peso a esta.

Algumas vertentes do assim chamado pós-modernismo parecem não perceber como suas bandeiras atrapalham ao rejeitar o valor do conhecimento verdadeiro universalmente aceitável e útil, ao enfatizar políticas identitárias, exagerando em seu apreço a culturas tradicionais - por mais que sejam baseadas em misticismo, obediência absoluta à autoridade tribal, ou simples crendice -, e rotulam conhecimentos por sua origem geográfica, falando de termos como "visão eurocêntrica" e reduzindo a ciência a um "discurso opressivo" (Glock, 2008, p. 232-242). Mas não. Independentemente de quem tenha feito alguma descoberta ou inventado alguma nova tecnologia, o critério pragmático é suficiente para validar ou invalidar um conceito, não importando quem tenha pensado primeiro e em que lugar, e não se faz nenhum favor às minorias em privá-las desse conhecimento. Pelo contrário. Os pensadores medievais, da tradição escolástica, já sabiam fazer esse discernimento para reconhecer o valor e estudar os escritos de Platão e Aristóteles, aos quais tiveram acesso por meio de papiros conservados pelos árabes. Independentemente de seu histórico e de sua origem, pagãos, o conhecimento naqueles escritos era bom e válido.

Por mais importante que o livro de Casagrande (2014) Mead e a educação tenha sido para a escrita deste trabalho, é preciso pontuar algumas falhas em sua análise. Ele está certo ao escrever que aprendizagem é sempre um processo interativo e que educação nunca deve ser entendida como mero despejo de conhecimentos nas mentes dos alunos. A mente humana, efetivamente, não é uma tábula rasa, mas, ao mesmo tempo, o autor parece incorrer em certos vícios da pedagogia construtivista, que peca pelo excesso, ao repudiar a "velha pedagogia" que prezava o processo de aprendizado passivo, em silêncio, em que o professor tem voz, e os alunos podem, no máximo, levantar a mão para perguntar (Casagrande, 2014, p. 89), rejeitando termos como "passar conhecimento" e ressaltando o processo como construção conjunta de significados.

De fato, não são os termos mais precisos para caracterizar o processo de aprendizagem, mas o erro do autor está em desconsiderar a falta de simetria entre mestre e aprendiz no tocante ao repertório de cada um. Seria truísmo dizer que o professor sabe mais que os alunos. Não é preciso rejeitar a natureza interativa da relação educando e educador para aceitar que uma parte do processo interativo consiste em tediosas lições de silenciosa aprendizagem e memorização, com as 
quais o aluno poderá raciocinar e efetivar esse conhecimento em sua vida dentro e fora da escola. A aprendizagem dá-se pela interpretação de gestos simbólicos, mas não se resume à atividade vocal ou locomotora: o aluno sentado em sua carteira ouvindo a aula ou debruçado sobre um livro não está estático nem passivo. Se está atento, em sua mente, há um intenso diálogo entre suas diversas formas interiores no esforço de assimilação.

Aqui se toma com cautela um artigo veementemente crítico ao construtivismo em geral (Haase, Júlio-Costa e Lopes Silva, 2015). Algumas das críticas que contém são corroboradas por evidências científicas, de maneira especial quanto à ordem de ensinar sintaxe e semântica. Os autores alegam que o cânone do construtivismo erra ao condenar o ensino do sentido da palavra antes da identificação das letras, das sílabas e dos respectivos fonemas, ou paralelamente a ela, conhecida como método fônico, defendido e comprovado, entre outros, pelo neurocientista Stanislas Dehaene (2009, p. 212), e por sobrecarregar a mente imatura dos jovens aprendizes, forçando-os a aprender e "pensar criticamente" em excesso, quando poderiam aprender muito mais facilmente se não precisassem "reinventar a roda". Nesse ponto, o artigo é razoável, pois não ter de despender tempo nem energia com problemas já resolvidos é a grande vantagem da transmissão cultural.

Naturalmente, mesmo um professor adepto da linha construtivista poderia acusar os autores do artigo em questão de fazer um espantalho dessa escola, alegar que nunca se segue tão à risca, simplesmente "deixando os alunos para aprenderem sozinhos”, e que se esquecem do papel social que independe de ideologias políticas e partidárias. O presente artigo também pretende valorizar e enquadrar adequadamente o papel social da instituição escolar, como não poderia ser diferente em qualquer trabalho acadêmico que assume a perspectiva de G. H. Mead.

A escola é um lugar privilegiado, dedicado ao conhecimento. A sala de aula é de importância inequívoca, mas não é só na aula que se aprende. $\mathrm{O}$ aluno na escola é colocado em um ambiente totalmente díspar daquele aconchegante e familiar do lar. Os alunos conversam e brincam, também. Em sua interação com outras crianças e com adultos, descobrem conflitos, nas brincadeiras aprendem a assumir outros papéis, tomar novas perspectivas. Por isso os autores do presente trabalho não veem com bons olhos a moda do homeschooling, que, a despeito de ser ilegal, tem milhares de adeptos no Brasil (Moraes, 2019).

O entendimento de Mead de escola é muito distinto daquele expresso pelas leituras de Michel Foucault mais corriqueiras, que podem não fazer justiça ao pensador francês, mas, independentemente disso, assombram por serem tão comuns no meio acadêmico brasileiro e pela visão negativa como retratam a escola, análoga a uma prisão, que sequestraria as crianças a fim de docilizá-las (Ferrari, 2008).

Mead de forma nenhuma pensava na escolarização como um sequestro, mas sim como uma extensão da relação familiar, e não a compreendia como docilização, porém como socialização. Em seu entendimento, não só a expectativa de vida do ser humano havia aumentado, como o tempo de sua infância vinha estendendo-se para muito além de sua infância biológica, e, ao mesmo tempo, o volume de cultura acumulada e de informação que tem de aprender é muito maior, sendo a educação familiar, ainda muito necessária, já não mais suficiente (Mead, 1940, p. 241). 
Nas palavras de seu discípulo Charles W. Morris, na introdução de Mind, self and society (Mead, 1940, p. 34, tradução nossa):

A ênfase do pragmatista na educação é o corolário lógico de sua teoria ética: Educação deve prover a técnica pela qual selves morais - inteligentes e socializados - devem ser desenvolvidos. Os artigos de Mead sobre a educação ressaltam cinco pontos:

1) A importância da escola em dar significados comuns, ferramentas linguísticas comuns.

2) O lugar da ciência no currículo.

3) A necessidade de atividades manipulativas, respondendo ao senso de realidade em fases de contato do ato.

4) A importância do ato de brincar como provedor do material para assumir papéis de outros, dos quais o selfé construído.

5) O papel da escola em formar selves morais.

No lar, toda criança, com ou sem irmãos, é especial e em geral recebe algum tratamento distinto. João e José podem ser irmãos e brigar pela atenção da mãe e do pai, mas estes adaptam o próprio cotidiano para dar a atenção e atender às necessidades de um e de outro. Fora do lar, a criança é introduzida em um ambiente com regras mais rígidas, horários e tarefas e colocada em condição de igualdade com outras crianças (a começar pelo uniforme). Assim - algumas com maior facilidade, outras com menor - a criança adapta-se, tentando novos gestos, vendo os resultados, desejáveis ou não, de tais gestos e construindo seu self.

Essa influência pesa muito mais na construção psicológica do ser do que qualquer outra. Como Steven Pinker (2003, p. 472-506) expõe em Tábula rasa, o debate de natureza contra criação já deveria ter se dado por encerrado há muito tempo, uma vez que já é bem sabido como genes e ambiente interagem, quais traços são moldados por um ou por outro e que a genética codifica tendências, não predestinações. De fato, trata-se de uma falsa dicotomia: genes, ambiente compartilhado (com os familiares, o lar) e ambiente não compartilhado, que o indivíduo frequenta e onde tem experiências únicas. Diversos experimentos que acompanharam gêmeos separados no nascimento e adotados por famílias diferentes atestam que a influência da criação é mínima, comparada com a dos genes e do ambiente único, tal qual o modo como o indivíduo se coloca no grupo (Pinker, 2003, p. 472-506). Mead não tinha como saber, tendo vivido e morrido algumas décadas antes de Watson e Crick vislumbrarem, pela primeira vez, a estrutura helicoidal da molécula de DNA, mas ele não tinha motivos para se preocupar: suas visões naturalista e interacionista não eram conflitantes, e, pelo contrário, a biologia veio a confirmar a disposição social e destrinchar os mecanismos por trás do processamento de símbolos e sua atuação na construção do self.

Isso pode se dar de maneira destrutiva, como é o caso do antigo fenômeno que só veio a ganhar notoriedade no século XXI, conhecido como bullying (Schultz et al., 2012), em que os piores instintos das crianças as levam a escolher algumas do grupo como indignas, seja por alguma peculiaridade física ou comportamental, 
seja por diferenças raciais, de classe social, entre outras. $\mathrm{O}$ resultado final quase sempre é o mesmo: a criança absorve aquela ideia que fazem dela, de uma pessoa inútil, incapaz, submissa. Por muito tempo, as escolas foram omissas quanto ao problema: "Ah, é só ignorá-los", resposta que muitas crianças vítimas de bullying ouviam quando iam se queixar aos professores ou autoridades escolares, como se tivessem maturidade suficiente para tal, se é que um adulto (que não um sociopata) seja capaz de tolerar o convívio em um lugar em que é humilhado e maltratado e permanecer inabalado. Tratando-se de crianças, o trauma é sempre mais profundo, a imagem que se constrói nessa primeira fase é muito difícil de mudar e leva o ser a desenvolver-se da pior forma possível.

Talvez essa atitude de descaso tenha sido padrão por tanto tempo não por indiferença em relação ao bem-estar das crianças, mas por desconhecer quão pernicioso é esse tipo de fenômeno, e muito disso poderia ter sido evitado se cada docente ou autoridade escolar tivesse como anteparo um conhecimento mínimo, mas ancorado na realidade, de como a formação do self se dá, de como o ambiente escolar é crítico para tal e de qual é o papel dos adultos em situações como tais, promovendo atividades de competição saudável, como os jogos das aulas de educação física, as olimpíadas de matemática e os concursos de redação, em que a competitividade é usada para encorajar cada criança a buscar vencer pelo empenho em realizar seu potencial e satisfazer-se por meio dele, e não pela sabotagem do esforço alheio nem com o objetivo de diminuí-la ou agredi-la. A competição saudável também é uma via para encorajar a cooperação, com equipes, gerando experiências que fazem toda a diferença no bem-estar psicológico de um indivíduo e em seu lugar na sociedade.

Essas relações pessoais, presentes no modelo teórico proposto por G. H. Mead, permitem compreender que entre os princípios morais de grande alcance está o respeito pelas pessoas, pois sentir respeito pelas pessoas, num sentido mais abstrato, é ser induzido pela ideia de que a outra pessoa é, afinal de contas, alguém como a gente e que, como tal, deve merecer certos direitos a ser tratada com consideração. Ou seja, Mead mobiliza elementos do pragmatismo para mostrar que a formação do self requer que igualdade e diferença coexistam nos processos de interação social, os quais vão permitir, ou negar, aos sujeitos o desenvolvimento de uma autorrelação saudável.

\section{REFERÊNCIAS}

ATKIN, A. Peirce's theory of signs. In: ZALTA, E. N. (ed.). The Stanford encyclopedia of Philosophy. Stanford: Stanford University, 2013. § 1.

BISACCIONI, P.; CARVALHO NETO, M. B. Algumas considerações sobre o "pequeno Albert". Temas em Psicologia, Ribeirão Preto, v. 18, n. 2, p. 491-498, 2010. Disponível em: http://pepsic.bvsalud.org/scielo.php?script=sci_arttext\&pid=S1413389X2010000200022. Acesso em: 28 nov. 2021.

CASAGRANDE, C. A. G. H. Mead \& a educação. São Paulo: Autêntica, 2014.

COSTA, C. F. Filosofia da linguagem. 4. ed. Rio de Janeiro: Jorge Zahar, 2002. v. 5. 
DAMÁSIO, A. R. Em busca de Espinosa. Tradução Laura Teixeira Motta. 2. ed. São Paulo: Editora Schwarcz, 2009.

DEHAENE, S.; CHANGEUX, J.-P.; NACCACHE, L.; SACKUR, J.; SERGENT, C. Conscious, preconscious, and subliminal processing: a testable taxonomy. Trends in Cognitive Sciences, Cambridge, v. 10, n. 5, p. 204-211, maio 2006. https://doi. org/10.1016/j.tics.2006.03.007

DEHAENE, S. Reading in the brain: the science and evolution of a human invention. 1. ed. Nova York: Viking, 2009.

DENNETT, D. C. Darwin's dangerous idea: evolution and the meanings of life. Nova York: Touchstone, 1995.

FERRARI, M. Michel Foucault, um crítico da instituição escolar. Nova Escola, São Paulo, 1 out. 2008. Disponível em: https://novaescola.org.br/conteudo/1522/michelfoucault-um-critico-da-instituicao-escolar. Acesso em: 1 ago. 2019.

GLOCK,H.J.What is analytic Philosophy? Cambridge: Cambridge University Press, 2008. HAACK, R. Wittgenstein's pragmatism. American Philosophical Quarterly, Oxford, v. 19, n. 2, p. 163-171, abr. 1982. Disponível em: https://www.jstor.org/stable/20013953. Acesso em: 28 nov. 2021.

HAASE, V. G.; JÚLIO-COSTA, A.; LOPES SILVA,J.B. Por que o construtivismo não funciona? Evolução, processamento de informação e aprendizagem escolar. Psicologia em Pesquisa, Juiz de Fora, v. 9, n. 1, p. 62-71, jun. 2015. https://doi.org/10.5327/ Z1982-1247201500010008

JAMES, W. The principles of Psychology. 1. ed. Nova York: Henry Holt and Company, 1918.v. 1.

JOAS, H. G. H. Mead: a contemporary re-examination of his thought. Tradução Raymond Meyer. Cambridge: The MIT Press, 1985.

JOAS, H.; HUEBNER, D. R. The timeliness of George Herbert Mead. Kindle Ed. ed. Chicago: The University of Chicago Press, 2016. E-book.

MEAD, G.H. Mind, self and society. 3. ed. Chicago: University of Chicago Press, 1940.

MORAES, I. Educação domiciliar: o homeschooling deve ser permitido no Brasil? [S.l.: s.n.], 2019.

NAGEL, T. Como é ser um morcego? Cadernos de História e Filosofia da Ciência, Campinas, v. 15, n. 3, p. 245-262, jan./jun. 2015. Disponível em: https://www.cle. unicamp.br/eprints/index.php/cadernos/article/view/617. Acesso em: 28 nov. 2021.

PINKER, S. Como a mente funciona. 2. ed. São Paulo: Companhia das Letras, 1998. PINKER, S. The blank slate: the modern denial of human nature. 2. ed. Nova York: Penguin, 2003.

SANTAELLA, L. O que é semiótica. São Paulo: Editora Brasiliense. 1983.

SCHULTZ, N. C.W.; DUQUE, D. F.; SILVA, C. F.; SOUZA, C. D.; ASSINI, L. C.; CARNEIRO, M. G.M. A compreensão sistêmica do bullying. Psicologia em Estudo, Maringá, v. 17, n. 2, p. 247-254, jun. 2012. Disponível em: https://www.scielo.br/j/pe/a/ 3s8Bkbw8Bc9nFR96vZj45Mm/?lang=pt\#. Acesso em: 28 nov. 2021. 
SEARLE, J. R.; DENNETT, D. C. The mystery of consciousness: an exchange. The New York Review, Nova York, v. 42, n. 20, dez. 1995. Disponível em: https://www. nybooks.com/articles/1995/12/21/the-mystery-of-consciousness-an-exchange/.Acesso em: 28 nov. 2021.

SOUZA, R. F. George Herbert Mead: contribuições para a história da psicologia social. Psicologia \& Sociedade, Belo Horizonte, v. 23, n. 2, p. 369-378, ago. 2011. https://doi. org/10.1590/S0102-71822011000200018

STERNBERG, R. J.; STERNBERG, K. Psicologia cognitiva. Tradução Marcelo Fernandes da Costa. 2. ed. São Paulo: Cengage Learning, 2016.

WITTGENSTEIN, L. Tractatus logico-philosophicus. Tradução, apresentação e estudo introdutório Luiz Henrique Lopes dos Santos; Introdução Bertrand Russell. 3. ed. São Paulo: EDUSP, 2001.

\section{SOBRE OS AUTORES}

Artur José da Renda Vitorino é doutor em história pela Universidade Estadual de Campinas (UNICAMP). Professor da Pontifícia Universidade Católica de Campinas (PUC-Campinas).

E-mail: arturvitorino@uol.com.br

Pedro Serafim Anes Pires é graduando em filosofia pela Pontifícia Universidade Católica de Campinas (PUC-Campinas).

E-mail: pedro.sap@outlook.com

Conflitos de interesse: Os autores declaram que não possuem nenhum interesse comercial ou associativo que represente conflito de interesses em relação ao manuscrito.

Financiamento: $\mathrm{O}$ estudo foi financiado pelo Fundo de Apoio à Iniciação Científica (FAPIC), da reitoria da Pontifícia Universidade Católica de Campinas (PUC-Campinas).

Contribuições dos autores: Conceituação, Curadoria de Dados, Escrita - Primeira Redação, Escrita - Revisão e Edição, Investigação, Metodologia, Obtenção de Financiamento, Recursos: Vitorino, A.J. R.; Anes Pires, P. S. Supervisão: Vitorino, A.J. R. 